\title{
Complementary Theories to Supply Chain Management
}

\author{
Halldorsson, Arni; Hsuan, Juliana; Kotzab, Herbert
}

Document Version

Final published version

Publication date:

2016

\section{License \\ CC BY-NC-ND}

Citation for published version (APA):

Halldorsson, A., Hsuan, J., \& Kotzab, H. (2016). Complementary Theories to Supply Chain Management. Abstract from 5th World Conference on Production and Operations Management. P\&OM 2016, Havana, Cuba.

Link to publication in CBS Research Portal

\section{General rights}

Copyright and moral rights for the publications made accessible in the public portal are retained by the authors and/or other copyright owners and it is a condition of accessing publications that users recognise and abide by the legal requirements associated with these rights.

\section{Take down policy}

If you believe that this document breaches copyright please contact us (research.lib@cbs.dk) providing details, and we will remove access to the work immediately and investigate your claim. 


\title{
Complementary Theories to Supply Chain Management
}

\author{
Arni Halldorsson (arni.halldorsson@chalmers.se) \\ Chalmers University of Technology, Dept. of Technology Management and Economics \\ Juliana Hsuan \\ Copenhagen Business School, Dept. of Operations Management \\ Herbert Kotzab \\ University of Bremen, Dept. of Logistics Management,
}

\section{Summary Abstract}

Borrowing from complementary theories has become an important part of theorizing SCM. We build upon principal-agent theory (PAT), transaction cost analysis (TCA), network theory (NT), and resource-based view (RBV) to provide insights on how to structure a supply chain and manage it. Through extensive literature review, we identified 76 articles of which a content analysis was performed on their appropriateness for PAT, TCA, NT and RBV. Our findings suggest that the integrative and multi-layered nature of SCM sets the conditions for "theorizing SCM" that can take place through various forms: theory application, new theoretical combinations and sensitivity to managerial practice.

Keywords: Supply Chain Management, Theories, Theorization

\section{Purpose}

Supply chain management has emerged as a profession as well as concept that is concerned with complex problems within and across the boundaries of the firm. An initial step in that development is the inter-organizational perspective it offers to traditional issues such as logistics, operations management and purchasing. Another milestone in the development is to enhance the explanatory power and problem solving capacity of the concept by borrowing from other fields such as strategic management and economics.

We view the supply chain is as a special form of an organization (i.e. borderless firm or an extended enterprise) where the problems that may arise often are associated with organizational and strategic matters (Halldórsson et al., 2007). Thereby, we argue that managerial principles of SCM must be built on a solid theoretical background that survives contemporary trends and buzzwords, and that allows users of theory (managers, students and researchers) to continuously advance their skills. In order to better understand as well as to reflect, we propose theories from fields such as economics, organization and strategic management, which are powerful enough to better understand the nature and dynamics of supply chain related problems. 
Borrowing from complementary theories has become an important part of theorizing $S C M$. In our first of two papers on this topic (Halldórsson et al., 2007) we discuss the development of supply chain management (SCM) from a socio-economic view and understand SCM as a scientific discipline to explain inter-organizational phenomena. Research has shown that there is no such thing as "unified theory of SCM". One can chose, however, one theory as the explanatory theory and use other theories to complement it. SCM has perhaps reached a level of maturity where it can be assigned an explanatory power by its contribution with inter-organizational dimensions to other academic fields and theories. We have built upon principal-agent theory (PAT), transaction cost analysis (TCA), network theory (NT), and resource-based view (RBV) as theories to provide insights on how to structure a supply chain and on how to manage a supply chain structure. We show how these four complementary theories can be applied in the context of third party logistics (TPL) and new product development (NPD).

From conceptual slack and constantly questioning towards intersections and actionable knowledge. In our second and more recent paper (Halldórsson et al., 2015) we propose that SCM suffers from a 'conceptual slack', and societal challenges and emerging business trends mean that SCM is 'constantly being questioned'. On the backdrop of this, we make use of Boyer's (1990) vocabulary on "academic scholarship" to provide a new perspective on the theorizing of SCM, that complements the previous 'borrowing from other disciplines' perspective.

\section{Design/methodology/approach}

We reviewed the titles of all articles published since 2007 in Journal of Operations Management (JOM), SCMIJ, IJPDLM, International Journal of Operations and Production Management (IJOPM) and JSCM for particular focus on application of theory and/or theory development. This search identified 76 articles, of which a content analysis was performed on their appropriateness for this research, namely PAT, TCA, NT and RBV. This yielded 54 papers, which were further categorized as one of two types of input into this discussion: a) application papers (32 papers), articles that present a specific problem (e.g. outsourcing) which was analyzed from a specific theoretical lens, and b) theorization papers (22 papers), articles that deal either with a discussion on SCM theory or with a theory development for SCM. In our second paper, this was followed up by a literature review of SCM and evaluation of application of theories identified in the first paper, and discussion of theory development.

\section{Findings}

The integrative and multi-layered nature of SCM sets the conditions for "theorizing SCM" that can take place through various forms: theory application, new theoretical combinations and sensitivity to managerial practice. We propose six building blocks of theorizing SCM: 1) SCM needs theorization, 2) The view of theorizing must reflect the nature of SCM, 3) From "borrowing" to "dialogue", 4) The four complementary theories (RBV, TCE, PAT, NT) are important to the evaluation of SCM, 5) using the four complementary theories in combination allows for a longitudinal approach to decision making in SCM, and 6) SCM inside. The second paper follows upon this and suggests that the integrative and multi-layered nature of SCM sets the conditions for "theorizing SCM" that can take place through various forms: theory application, new theoretical combinations and sensitivity to managerial practice. It is pivotal that future research explores further the performative potential of SCM. 


\author{
World P\&OM Conference \\ Havana, Cuba \\ September 6-10, 2016
}

\title{
Relevance/contribution
}

Research with focus on theory development or using complementary theories to advancing understanding of SCM can benefit from the five building blocks of theorizing SCM proposed in the second paper. In particular, to enhance the relevance and problem solving capacity of our frameworks, theoretical principles in SCM should not only be used to describe practical problems but also to "produce the world"; supply chains can be seen as organizational units that act or consummate an action that delivers a particular performance.

\section{References}

Boyer, E.L. (1990), Scholarship Reconsidered: Priorities of the Professoriate, Carnegie Foundation for the Advancement of Teaching, Princeton, NJ.

Halldórsson, Á., Kotzab, H., Mikkola, J.H., Skjoett-Larsen, T. (2007), “Complementary theories to supply chain management”, Supply Chain Management: An International Journal, Vol. 12, No. 4, pp. 284296.

Halldórsson, Á., Hsuan, J. and Kotzab, H. (2015), “Complementary theories to supply chain management revisited - from borrowing theories to theorizing", Supply Chain Management: An International Journal, Vol. 20, No. 6, pp.574 - 586. Link: http://www.emeraldinsight.com/doi/abs/10.1108/SCM$\underline{06-2015-0228}$ 